\title{
Mekanisme Pengembalian Kerugian Negara oleh Terpidana yang Meninggal Dunia Pasca Putusan Mahkamah Konstitusi Nomor 25/PUU-XIV/2016
}

\author{
Erwin Ubwarin', Yonna Beatrix Salamor ${ }^{2}$ \\ ${ }^{1}$ Program Studi Ilmu Hukum, Universitas Pattimura Ambon \\ Email:eubwarin@gmail.com \\ ${ }^{2}$ Program Studi Ilmu Hukum, Universitas Pattimura Ambon \\ Email:yonnahukum@gmail.com
}

\begin{abstract}
ABSTRAK
Putusan Mahkamah Konstitusi Nomor 25/PUU-XIV/2016 mengahapuskan kata "dapat" pada rumusan Pasal 2 ayat (2) dan Pasal 3, dari rumusan delik formil menjadi delik materiil, pembuktian kerugian negara yang awalnya potential loss berubah ke actual loss, dari berpontensi ke kerugian nyata. Kerugian Negara yang telah dibuktikan harus dikembalikan tidak bisa dilakukan oleh jaksa sebagai eksekutor untuk terpidana yang meninggal dunia.Tujuan penelitian ini adalah untuk menemukan mekanisme pengembalian kerugian Negara bagi terpidana meninggal dunia. Metode yang digunakan dalam penelitian ini adalah yuridis normatif. Hasil penelitian menunjukan dalam Undang-undang Nomor 31 Tahun 1999 jo. Undang-undang Nomor 20 Tahun 2001 tentang Pemberantasan tindak pidana korupsi, tidak mengatur tentang mekaniseme pengembalian kerugian Negara untuk terpidana yang meninggal dunia karena bertentangan dengan Pasal 83 KUHP, seharusnya Undang-Undang Nomor 31 Tahun 1999 jo. Undang-Undang Nomor 20 Tahun 2001 tentang Pemberantasan tindak pidana korupsi, dapat mengejar kerugian Negara karena Putusan Mahkamah Kostitusi Nomor 25/PUU-XIV/2016 telah merubah rumusan kerugian Negara dalam Pasal 2 ayat (1) dan Pasal 3 Undang-Undang Nomor 31 Tahun 1999 jo. UndangUndang Nomor 20 Tahun 2001 tentang Pemberantasan tindak pidana korupsi menjadi actual loss, jika dibandingkan dengan Undang-Undang Nomor 7 Drt 1955 tentang Pengusutan, Penuntutan dan Peradilan Tindak Pidana Ekonomi Pasal 13 ayat 1 dengan meninggalnya terpidana hak melaksanakan perempasan tidak lenyap. kesimpulannya Pasal 103 KUHP dan asas Lex specialis derogat legi generali membuka peluang untuk penyimpangan Pasal 83 KUHP, memasukan mekanisme pengembalian kerugian Negara bagi terpidana dengan merevisiUndang-undang Nomor 31 Tahun 1999 jo. Undang-Undang Nomor 20 Tahun 2001 tentang Pemberantasan tindak pidana korupsi.
\end{abstract}

Kata kunci: Mekanisme, Kerugian Negara, Tindak Pidana Korupsi

\section{PENDAHULUAN}

Bangsa Indonesia yang sedang giat dalam melaksanakan pembangunan sangat membutuhkan suatu kondisi yang dapat mendukung terciptanya tujuan pembangunan nasional yaitu masyarakat adil dan makmur berdasarkan Pancasila. Salah satu kondisi tersebut adalah penegakan supermasi hukum yang merupakan syarat mutlak (condition sine qua non) bagi kelangsungan dan keberhasilan pelaksanaan pembangunan nasional sesuai dengan jiwa reformasi (geweten). Untuk itu memujudkan hal tersebut perlu ditingkatkan usaha-usaha untuk memelihara ketertiban, keamanan, kedamaian dan kepastian hukum yang mampu mengayomi segenap masyarakat yang ada, antara lain dengan pencegahan dan pemberantasan tindak pidana korupsi (Iskandar, 2015, h. $1)$.

Secara etimologis, korupsi berasal dari bahasa Latin yaitu corruption atau corruptus, dan istilah bahasa Latin yang lebih tua dipakai istilah corumpere. Dari bahasa Latin, seperti bahasa bangsabangsa di Eropa seperti Inggris: corruption, Prancis: corruption, dan Belanda:corruptive dan korruptie, yang kemudian turun kedalam bahasa Indonesia menjadi Korupsi. Arti harafiah dari kata itu ialah kebusukan, keburukan, kebejatan, ketidak jujuran, dapat disuap, tidak bermoral, penyimpangan dari kesucian (Hamzah, 1991, h.7).

Didalam Undang-Undang No 31 tahun 1999 tentang Pemberantasan Tindak Pidana Korupsi yang kemudian diamandemen melalui Undang-Undang No. 20 tahun 2001 tidak ada Pasal tentang mekanisme pengembalian kerugian Negara yang timbul bagi terpidana yang meninggal dunia.Karena terpidana yang telah meninggal dunia, putusan pengadilan atas dirinya tidak dapat 
di eksekusi karena dalam Pasal 83 Kitab Undang-undang Hukum Pidana (KUHP) menyebutkan bahwa "Kewenangan menjalankan pidana hapus jika terpidana meninggal dunia". Menurut Wirjono Prodjodikoro:

Apabila terdakwa meninggal dunia setelah dijatuhi hukuman dengan putusan yang mempunyai kekuatan hukum tetap, maka menurut Pasal 83 KUHP gugurlah hak untuk mejalankan hukumannya, termasuk hukuman tambahan seperti perampasan barangbarang (Prodjodikoro, 2010, h.156).

Padahal tindak pidana korupsi tergolong dalam hukum pidana khusus yang dapat menyampingkan peraturan pidana yang umum yang diatur dalam KUHP, penyimpangan dapat didasarkan pada asas preferensi hukum (Lex specialis derogat legi generali) peraturan yang khusus menyampingkan peraturan yang umum.

Tindak pidana korupsi mengakibatkan timbulnya kerugian Negara dan atau perekonomian Negara.Setelah diterbitkannya Undang-Undang No 31 tahun 1999 tentang Pemberantasan Tindak Pidana Korupsi yang kemudian diamandemen melalui Undang-Undang No. 20 tahun 2001, maka dalam Pasal 2 ayat (1) merumuskan tindak pidana korupsi adalah: "setiap orang yang secara melawan hukum melakukan perbuatan memperkaya diri sendiri atau oang lain atau suatu korporasi yang dapat merugikan keuangan Negara atau perekonomian Negara, dipidana dengan pidana penjara seumur hidup atau pidana penjara paling singkat 4 (empat) tahun dan paling lama 20 (dua puluh) tahun dan denda paling sedikit Rp. 200.000.000,- (dua ratus juta rupiah) dan paling banyak Rp. 1.000.000.000,- (satu milyar rupiah)

Dalam Pasal 3-nya dirumuskan: "setiap orang dengan tujuan menguntungkan diri sendiri atau orang lain atau korporasi, menyalahgunakan kewenangan, kesempatan, atau sarana yang ada padanya karena jabatan atau kedudukan yang dapat merugikan keuangan negara atau perekonomian negara, dipidana dengan pidana penjara seumur hidup atau pidana penjara paling singkat 1 (satu) tahun dan paling lama 20 (dua puluh) tahun dan denda paling sedikit Rp. 50.000.000,- (lima puluh juta rupiah) dan paling banyak Rp. 1.000.000.000,- (satu milyar rupiah)".

Hal ini berubah ketika Putusan Mahkamah Kontitusi 25/PUU-XIV/2016, dalam amar putusannya menyebutkan bahwa menyatakan kata "dapat" dalam Pasal 2 ayat (1) dan Pasal 3 Undang-undang Nomor 31 Tahun 1999 tentang Pemberantasan Tindak Pidana Korupsi sebagaimana diubah dengan Undang-Undang Nomor 20 Tahun 2001 tentang Pemberantasan Tindak Pidana Korupsi bertentangan dengan Undang-undang Dasar Negara Republik Indonesia Tahun 1945 dan tidak mempunyai kekuatan mengikat. Atas putusan ini maka rumusan Pasal 2 ayat (1) dan Pasal 3 Undang-undang Nomor 31 Tahun 1999 jo. Undang-Undang Nomor 20 Tahun 2001 tentang Pemberantasan Tindak Pidana Korupsi (selanjutnya disebut UU TIPIKOR) untuk rumusan delik formil ke delik materiil, kerugian Negara tidak lagi sebagai potential lossnamun keactual loss, hal ini menyulitkan pembuktian kerugian Negara namun untuk mengejar kerugian Negara lebih mudah.

\section{METODE PENELITIAN}

Metode penelitian dapat diartikan sebagai suatu sarana yang penting guna menemukan, mengembangkan serta menguji kebenaran suatu pengetahuan. Menurut Soerjono Soekanto metodelogi merupakan unsur mutlak yang harus ada di dalam penelitian dan pengembangan ilmu pengetahuan (Soekanto, 1984,hal.7). Oleh karena itu, untuk menunjang penulisan ini maka metode penelitian yang penulis gunakan adalah sebagai berikut : 
1. Jenis Penelitian

Jenis Penelitian yang digunakan dalam penelitian ini. Yuridis Normatifdengan menggunakan pendekatan perundang-undangan (statute approach) dan pendekatan konseptual.Menurut Peter Mahmud Marzuki, pendekatan perundang-undangan (statute approach) dan pendekatan konseptual dilakukan dengan menelaah semua undang-undang dan regulasi yang bersangkut paut dengan isu hukum yang sedang ditangani(Marzuki, 2007, h.1).

2. Tipe Penenelitan

Tipe penelitian yang dipakai dalam penulisan ini adalah bersifat Deskriptif Analitis. Penelitian Deskriptif Analitis adalah jenis penelitian yang bertujuan untuk mengungkapkan fakta, keadaan, fenomena, dan variabel yang terjadi saat penelitian berjalan dan menyuguhkan apa adanya. Pengumpulan bahan hukum, menganalisis bahan hukum, menginterprestasi bahan hukum, dan diakhiri dengan sebuah kesimpulan yang mengacu pada penganalisisan bahan hukum yang penulis teliti.

3. Sumber Bahan Hukum

Untukmendukung pendekatan masalah di atas, sumber bahan hukum yang dipilih untuk digunakan yaitu bahan hukum primer dan bahan hukum sekunder (Nasution, 2008, h. 56).

i. Bahan Hukum Primer

Bahan hukum primer merupakan bahan hukum yang bersifat mengikat(Soemitro, 1980:12), yang terdiri dari peraturan perundang-undagan yang terkait dengan permasalahan yang diambil, yaitu:

1) Undang-Undang Dasar 1945;

2) KUHP ( Kitab Undang-Undang Hukum Pidana ).

3) KUHAP ( Kitab Undang-Undang Hukum Acara Pidana ).

4) Undang-Undang Nomor 31 Tahun 1999 dan perubahannya Undang-Undang Nomor 20 Tahun 2001 tentang Tindak Pidana Korupsi

5) Undang-undang Nomor 17 Tahun 2003 tentang Keuangan Negara

ii. Bahan Hukum Sekunder

Bahan hukum sekunder merupakan bahan hukum yang mendukung bahan hukum primer, yang mana terdiri dari :

1) Majalah hukum;

2) Jurnal hukum dan

4. Teknik Pengumpulan dan AnalisisBahan Hukum.

Bahan hukum primer dan sekunder dikumpulkan dengan cara menghimpun undang-undang dan peraturan-peraturan lainnya yang berkaitan dengan masalah yang dibahas, yang mana pengumpulan bahan hukum tersebut dilakukan dengan cara menginventarisasi dan mengklasifikasi bahan hukum yang sesuai dengan masalah yang dibahas, setelah itu bahan hukum yang berhubungan dengan masalah dipaparkan, disusun, kemudian dianalisis untuk menginterpretasikan hukum yang berlaku.

Berdasarkanbahan hukum yang sudah dikumpulkan baik bahan hukum primer maupun bahan hukum sekunder, maka teknik analisa yang digunakan dalam penulisan ini adalah teknik analisis kualitatif (Soemitro, 1980, h. 51),yakni hasil yang dianalisis hanyalah hal-hal yang bersifat mendasar dari apa yang di teliti.

\section{HASIL DAN PEMBAHASAN}

Di Indonesia, ada beberapa kasus yang esekusi oleh Jaksa sebagai esekutor atas suatu putusan pengadilan yang telah mempunyai kekuatan hukum tetap(inkracht van gewijsde) namun sulit dilakukan karena terpidana tindak pidana korupsi telah meninggal dunia seperti : 
Table 1. Data Terpidana Tindak Pidana Korupsi Yang Meninggal Dunia

\begin{tabular}{llll}
\hline No. & \multicolumn{1}{c}{ Tindak Pidana Korupsi } & $\begin{array}{l}\text { Kerugian Negara yang belum } \\
\text { dikembalikan }\end{array}$ \\
\hline 1 & $\begin{array}{l}\text { Panitera Sekretaris PN Surabaya. Modusnya, Terpindana M tidak } \\
\text { memasukkan uang pendaftaran perkara gugatan ke kas Negara } \\
\text { (Tahun 1993) }\end{array}$ & $\begin{array}{l}\text { Rp.600.000.000 (enam ratus juta } \\
\text { rupiah) }\end{array}$ \\
\hline 2 & $\begin{array}{l}\text { Kasus Tindak Pidana Korupsi dalam penyelenggaraan } \\
\text { Musabaqah Tilawatil Quran (MTQ) XXIV tingkat Maluku di 250.000.000 (dua ratus lima } \\
\text { puluh juta rupiah) }\end{array}$ & \\
& $\begin{array}{l}\text { Kota Dobo Kab. Kepulauan Aru tahun 2011, dengan terpidana } \\
\text { UD sebagai Wakil Bupati Kab. Kepulauan Aru (Tahun 2013) }\end{array}$ & \\
\hline 3 & $\begin{array}{l}\text { Terpidana S, tindak pidana korupsi dana milik Perusahaan } \\
\text { Daerah (PD) Badan Kredit Kecamatan (BKK) Eromoko, } \\
\text { Wonogiri (Tahun 2016) }\end{array}$ & rupiah \\
\hline
\end{tabular}

Dari data tersebut dapat dilihat bahwa uang Negara yang harusnya dikembalikan kepada Negara menjadi hilang karena terpidana telah meninggal dunia sebagaimana diatur dalam Pasal 83 KUHP,Pasal ini membatasi jaksa sebagai esekutordalam pengembalian kerugian Negara bagi terpidana yang meninggal dunia, hal ini berberda dengan terdakwa dan tersangka, Asisten Tindak Pidana Khusus Kejati Maluku, mengatakan bahwa: sampai sekarang kejaksaan mengalami kesulitan terhadap mekanisme terpidana korupsi yang meninggal dunia.

Pasal 103 KUHP membuka peluang untuk penyampingan terhadap Pasal 83 KUHP, jika dilihat dalam UU TIPIKOR hanya mengatur tentang bagaimana mekanisme proses pengembalian kerugian Negara bagi tersangka dan terdakwa yang meninggal dunia baik dalam proses penyidikan maupun proses peradilan, hal ini sebagaimana diatur dalam:

Pasal 33 : Dalam hal tersangka meninggal dunia pada saat dilakukan penyidikan, sedangkan secara nyata telah ada kerugian keuangan negara, maka penyidik segera menyerahkan berkas perkara hasil penyidikan tersebut kepada Jaksa Pengacara Negara atau diserahkan kepada instansi yang dirugikan untuk dilakukan gugatan perdata terhadap ahli warisnya.

Pasal $34 \quad$ : Dalam hal terdakwa meninggal dunia pada saat dilakukan pemeriksaan di sidang pengadilan, sedangkan secara nyata telah ada kerugian keuangan negara, maka penuntut umum segera menyerahkan salinan berkas berita acara sidang tersebut kepada Jaksa Pengacara Negara atau diserahkan kepada instansi yang dirugikan untuk dilakukan gugatan perdata terhadap ahli warisnya.

Pelaksanaan untuk menjalankan pidana secara otomatis akan menjadi terhapus dengan meninggalnya terpidana. Logikanya adalah tidak mungkin untuk tetap membiarkan seorang yang telah meninggal dunia untuk selamanya berada di penjara sekalipun dia adalah penjahat yang paling sadis. Masalahnya sekrang, bagaimanakah dengan eksekusi pidana denda? apakah esekusi pidana akan diteruskan oleh ahli waris tatkala terpidana meninggal dunia? pada masa HIR (HerzienInlandschReglement) memang diatur bahwa dalam perkara pajak dan cukai, maka pidana denda dan perampasan serta biaya-biayanya dibebankan kepada ahli waris (Pasal 368 HIR). Namun demikian, ketentuan tersebut tidak diatur oleh KUHAP(Suarda, 2012, h. 148). Soesilo menjelaskan atas putusan yang telah mempunyai kekuatan hukum tetap tidak bisa di eksekusi oleh Jaksa Penuntut Umum yaitu:

Untuk perkara mengenai cukai dan penghasilan Negara, Negara dapat menjalakan pidana denda atau perampasan barang-barang untuk mengembalikan kerugian atas tindakan yang dilakukan terpidana. contohnya dalam Pasal 367 dan 363 HIR (sudah tidak berlaku) (Soesilo, 2007, h. 91). 
Tidak berlakunya kententuan penerapan pidana denda dan perampasan harta terpidana yang telah meninggal dunia berdasarkan adagium nemo punitur pro alieno delikto, yang berarti tidak ada seorangpun yang dihukum karena perbuatan orang lain, secara mutatis mutandis adagium a quo juga berlaku terhadap gugurnya menjalani pidana karena terpidana meninggal dunia sesuai Pasal 83 KUHP (Heariej, 2014, h. 378).

Dalam HIR juga menganut secara umum adagium a quo namun secara khusus untuk tindak pidana tertentu dapat menyampingkan adagium a quo. "tidak ada seorangpun yang dihukum karena perbuatan orang lain" seorang ahli waris tidak dapat dijatuhi pidana denda dan pidana perampasan barang "hanya dalam kasus cukai dan penerimaan Negara", Menurut Pasal 367 HIR maka ketentuan tersebut harus dikecualikan sepanjang mengenai penagihan denda atau perampasan barang-barang tertentu di dalam pelanggaran tentang penghasilan negara dan cukai. Hal ini berarti, bahwa meskipun terdakwanya, karena meninggal, tidak lagi dapat dihadapkan di muka hakim, putusan pidana denda dan perampasan barang-barang tertentu di dalam pelanggaran tersebut tadi, dapat dijatuhkan juga.

Menurut penulis dengan dikeluarkan Putusan Mahkamah Kostitusi Nomor 25/PUU-XIV/2016, dalam amar putusannya mengapuskan kata "dapat"dalam Pasal 2 ayat (1) dan Pasal 3 UU TIPIKOR merupakan jalan masuk untuk mekanisme pengembalian kerugian Negara karena pembuktian kerugian Negara telah selesai di agenda sidang pembuktian, sehingga hasil pembuktian actual loss, sebelum putusan makahmah kostitusi merubah Pasal 2 ayat (1) dan Pasal 3 UU Tipikor dari delik formil pembuktian mencari potential loss, yang dimakudkan delik formil adalah delik yang menitikberatkan pada tindakan, sedangkan delik materiil adalah delik menitik beratkan pada akibat (Hiariej, 2014:103). Dengan hilangnya kata dapat dalam frasa "dapat merugikan kerugian Negara atau perekonomian negara" maka rumusan delik Pasal 2 ayat (1) dan Pasal 3 menjadi delik materiil, kerugian harus dibuktikan dalam sidang pembuktian secara actual loss, jika sudah ada kerugian Negara yang pasti,akan dijatukan "pidana denda" dan "pidana perampasan barang tertentu".Untuk memenuhi rasa keadilan kerugian Negara harus dikembalikan.

Seharusnya ada Pasal yang mengatur tentang mekanisme pengembalian kerugian Negara bagi terpidana meninggal dunia dengan menerapkan pidana denda danperampasan barang tertentu, hal ini dapat dilihat dalam:

Pasal 18Ayat (1)

: Selain pidana tambahan sebagaimana dimaksud dalam Kitab UndangUndang HukumPidana, sebagai pidana tambahan adalah:

a. perampasan barang bergerak yang berwujud atau yang tidak berwujud atau barangtidak bergerak yang digunakan untuk atau yang diperoleh dari tindak pidanakorupsi, termasuk perusahaan milik terpidana di mana tindak pidana korupsi dilakukan, begitu pula dari barang yang menggantikan barang-barang tersebut;

b. pembayaran uang pengganti yang jumlahnya sebanyakbanyaknya sama denganharta benda yang diperoleh dari tindak pidana korupsi;

c. penutupan seluruh atau sebagian perusahaan untuk waktu paling lama 1 (satu)tahun;

d. pencabutan seluruh atau sebagian hak-hak tertentu atau penghapusan seluruhatau sebagian keuntungan tertentu, yang telah atau dapat diberikan olehPemerintah kepada terpidana. 
Jika diperhatikan dalam UU TIPIKOR juga menyampingkan adagium nemo punitur pro alieno delikto hal ini dilihat dalam :

Pasal 38

Ayat (5)

Ayat (6)
Dalam hal terdakwa meninggal dunia sebelum putusan dijatuhkan dan terdapat bukti yang cukup kuat bahwa yang bersangkutan telah melakukan tindak pidana korupsi, maka hakim atas tuntutan penuntut umum menetapkan perampasan barang-barang yang telah disita

: Penetapan perampasan sebagaimana dimaksud dalam ayat (5) tidak dapat dimohonkan upaya banding.

Dalam Pasal 38 ayat (5) telah jelas bahwa telah terjadi penyimpangan atas adagium nemo punitur pro alieno delikto, tentunya dapat diberlakukan bagi terpidana yang meninggal dunia.

Dengan merevisi UU TIPIKOR dengan memasukan pasal tentang mekaniseme pegebalian kerugian Negara bagi terpidana yang telah meninggal dunia.Penyampingan Pasal 83 KUHP dapat dicontohi dalamUndang-Undang Nomor 7 Drt 1955 tentang Pengusutan, Penuntutan Dan Peradilan Tindak Pidana Ekonomi (selanjutnya disebut UU TPE) menyebutkan :

Pasal 13 ayat (1) : Hak melaksanakan perempasan tidak lenyap dengan meninggalnya terhukum

UU TPE, menyampingkan Pasal 83 KUHP dengan tetap melakukan perampasan terhadap barang bukti yang telah disita oleh sebelum terpidana meninggal untuk menutupi kerugian Negara dan atau perekonomian Negara yang timbul akibat tindak pidana ekonomi yang dilakukan. Tidak Pidana Ekonomi yang telah terbukti kerugian Negara atau perekonomian Negara dalam sidang pembuktian harus dikembalikan.UU TPE merupakan bentuk penyimpangan dan juga termasuk pidana khusus sama dengan tindak pidana korupsi. Dalam Tindak Pidana korupsi juga dapat merampas barang-barang tertentu terpidana (Pidana Tambahan) dan atau pidana denda (Pidana Pokok) untuk menutupi kerugian Negara dengan merevisi UU TIPIKOR.

\section{KESIMPULAN}

Putusan Mahkamah Konstitusi Nomor 25/PUU-XIV/2016 dalam amar putusannya membatalkan kata dapat dalam frasa dapat merugikan "kerugian Negara atau perekonomian Negara "pada Pasal 2 ayat (1) dan Pasal 3 hal ini membuat pembuktian delik formil berubah menjadi delik materiil, hal ini berguna dalam upaya pengembalian kerugian Negara karena sudah ada jumlah yang jelas kerugian Negara (actualloss). Kejelasan ini mempermudah pengembalian kerugian Negara dengan menyampingkan Pasal 83 KUHP, bagi terpidana yang meninggal dunia, namun dalam penegakan hukumnya sulit dilakukan karena ada adagium nemo punitur pro alieno delikto, namun UU TIPIKOR sendiri telah menyampingkan adagium dan Pasal 83 KUHP yaitu Pasal 38 ayat (5) mekanisme pidana dengan menjatukan pidana denda dan pidana tambahan bagi terdakwa yang meninggal dunia, namun belum ada mekanisme pengembalian kerugianNegara bagi terpidana yang meninggal dunia, untuk itu perlu amandemen UU TIPIKOR dengan memasukan mekanisme pengembalian kerugian Negara oleh terpidana yang telah meninggal.

\section{Ucapan Terima Kasih}

Kami menyadari bahwa karya ilmiah berasil dirampungkan tidak lepas dari pihak-pihak yang telah membantu baik secara materiil dan formil untuk itu kami mengucapkan terima kasih kepada :

a. Tuhan Yang Maha Esa yang selalu memberkati dan menyertai kami dalam melakukan penelitan ini.

b. Ketua Pengadilan Negeri Ambon, yang telah banyak membantu berdiskusi dan memberikan pengalaman dalam penangganan Pengadilan Korupsi di Pengadilan Negeri Ambon 
c. Ketua Kejaksaan Tinggi Maluku, yang telah banyak memberikan masukan dan pengalaman dalam melakukan penegakan hukum dalam tindak pidana korupsi.

d. Dekan Fakultas Hukum Universitas Pattimura, yang selalu memberikan semangat dan motivasi.

e. Ketua Lembaga Penelitian dan Pengabdian Universitas Pattimura, yang banyak memberikan bahan-bahan hukum sebagai penunjang dalam penelitian ini.

f. Panitia Seminar Nasional Universitas Riset Multi Disiplin Taruma Negara Tahun 2017, yang telah memberikan kami kesempatan sebagai Dosen dengan jabatan akademik Asisten Ahli untuk mengikuti kegiatan seminar nasional riset multi disiplin.

\section{REFERENSI}

Hamzah, A. (1991). Korupsi di Indonesia Masalah Dan Pemecahannya. Jakarta: Gramedia Pustakan Utama.

Hiariej, E. O. (2014). Prinsip-prinsip Hukum Pidana. Yogyakarta: Cahaya Atma Pustaka.

Iskandar, M. A. (2015). Perluasan Penyertaan Tindak Pidana Korupsi Menurut UNCATOC 2000 dan UNCAC 2003. Jakarta: GP Press.

Mahmud, P. M. (2007). Penelitian Hukum. Jakarta: Media Group.

Nasition, J. B. (2007). Metode Penelitian Hukum. Jakarta: Mandar Maju.

Prodjodikoro, W. (2010). Asas-asas Hukum Pidana di Indonesia. Bandung: Eresco.

Soekanto, S. (1984). Pengantar Penelitian Hukum. Jakarta: UI Press.

Soemitro, R. H. (1980). Metodologi Penelitian Hukum dan Jurimetri. Jakarta: Ghalia Indonesia.

Soesilo, R. (2007). Kitab Undang-undang Hukum Pidana (Serta Komentar-komentarnya Lengkap Pasal Demi Pasal). Bogor: Politeia.

Sudarda, I. G. (2012). Hukum Pidana (Materi Penghapus, Peringan dan Pemberat Pidana. Malang: Bayumedia Publising. 